\title{
HOT-DEFORMATION BEHAVIOUR AND FLOW-STRESS PREDICTION OF THE TC4 ALLOY CONSIDERING STRAIN
}

\author{
OBNAŠANJE ZLITINE TC4 MED VROČO DEFORMACIJO IN \\ NAPOVED NAPETOSTI TEČENJA GLEDE NA STOPNJO \\ DEFORMACIJE
}

\author{
Fei Han ${ }^{1}$, Yun Wang1, Rongquan Chen'1, Qi Gao², Yongqiang Wang'2, Dingchun Wang ${ }^{2}$ \\ ${ }^{1}$ School of Mechanical and Materials Engineering, North China University of Technology, no. 5 Jinyuanzhuang Road, Shijingshan District, \\ Beijing 100144, China \\ ${ }^{2}$ Baoti Group Ltd, no. 88 Gaoxin Avenue, Baoji City, Shaanxi Province 721014, China
}

Prejem rokopisa - received: 2018-07-12; sprejem za objavo - accepted for publication: 2018-09-20

doi:10.17222/mit.2018.143

To study the hot-compressive deformation behaviour of the TC4 alloy, isothermal compression tests were conducted at temperatures ranging from $700{ }^{\circ} \mathrm{C}$ to $900{ }^{\circ} \mathrm{C}$, at $100{ }^{\circ} \mathrm{C}$ intervals, and at strain rates ranging from $0.1 \mathrm{~s}^{-1}$ to $10.0 \mathrm{~s}^{-1}$. The experimental results showed that the flow stress of the TC4 alloy increases quickly with an increase in the strain, reaches a peak value, and then decreases to a steady value. The results clearly indicated that dynamic recovery and recrystallization occur during the hot-compression tests. The flow stress of the TC4 alloy increases with a decrease in the deformation temperature and an increase in the strain rate. On the basis of the experimental results, a revised constitutive model describing the relationship among the flow stress, strain rate, and forming temperature of the TC4 alloy at elevated temperature was established. The flow-stress values predicted by the constitutive model agreed well with the experimental results.

Keywords: TC4 alloy, flow stress, constitutive model

Avtorji so izvajali preizkuse vroče izotermalne deformacije pod tlakom na zlitini TC4 v temperaturnem območju med $700{ }^{\circ} \mathrm{C}$ in $900{ }^{\circ} \mathrm{C}$, v intervalih po $100{ }^{\circ} \mathrm{C}$ in hitrostih deformacije od $0,1 \mathrm{~s}^{-1}$ do $10,0 \mathrm{~s}^{-1}$. Rezultati eksperimentov so pokazali, da $\mathrm{z}$ naraščajočo stopnjo deformacije hitro narašča napetost tečenja zlitine TC4. Ko doseže vrh, začne padati in se ustali pri neki konstantni vrednosti. Rezultati so jasno pokazali, da med preizkusi vroče deformacije pod tlakom pride do dinamične poprave in rekristalizacije. Napetost tečenja zlitine TC4 narašča z zniževanjem temperature deformacije in narašča s hitrostjo deformacije. $\mathrm{Na}$ osnovi rezultatov so avtorji revidirali in potrdili konstitutivni model, ki opisuje zvezo med napetostjo tečenja, hitrostjo in temperaturo deformacije zlitine TC4. Numerično napovedana napetost tečenja zlitine se dobro ujema z rezultati eksperimentov.

Ključne besede: zlitina TC4, napetost tečenja, konstitutivni model

\section{INTRODUCTION}

The TC4 alloy, a typical $\alpha+\beta$ titanium alloy, has been widely used in aerospace materials, chemical pressure vessels, medical surgical implants, military armour, etc., owing to its low density, attractive specific strength, excellent corrosion resistance, and good combined thermal and mechanical behaviour. ${ }^{1-3}$ Hot deformation is a key effective method for forming metallic components. Although in some studies the flow behaviour of the TC4 alloy has been examined, the uncertainty and complexity of the flow behaviour under hot-working conditions are not fully understood. Hotcompression deformation testing is useful for investigating the hot-deformation behaviour during hot-working conditions. Bobbili et al. ${ }^{4}$ and Cai et al..$^{5}$ found that during thermal processing, the temperature, strain, and strain rate significantly affect the flow stress of titanium alloys. A comprehensive understanding of the material flow behaviour is very important for designing hot-working processes.

*Corresponding author e-mail:

hanfei@ncut.edu.cn
A finite-element simulation is an economical and effective tool for simulating a material's flow behaviour and optimising the forming parameters of a material. In a finite-element simulation, a constitutive equation that describes the correlation of the flow stress with the processing parameters is necessary to predict the dynamic flow behaviour and optimise the deformation process of metallic materials. ${ }^{6-10} \mathrm{Kim}$ et al., ${ }^{11}$ Wang et al., ${ }^{12}$ and Xiao et al. ${ }^{13}$ found that the flow behaviour of the TC4 alloy is sensitive to the processing parameters, such as the deformation temperature and the strain rate during high-temperature deformation. To precisely describe the material flow behaviour, a number of constitutive models have been established or modified. Yuan et al. ${ }^{14}$ proposed a modified constitutive equation based on multiple nonlinear regression, where the independent effects of the strain, strain rate, and temperature and their interrelations were considered. Kotkunde et al. ${ }^{15}$ investigated the flow behaviour of the TC4 alloy by comparing four constitutive models, the modified Johnson-Cook model, modified Arrhenius-type equations, and modified Zerilli-Armstrong and Rusinek-Klepaczko models, to predict the flow stress. Li et al. ${ }^{16}$ proposed a forming- 
limit prediction model of the TC4 alloy that takes the strain rate and temperature sensitivity into account and is based on the Marciniak-Kuczynski theory and von Mises yield criterion. Kotlyarenko et al. ${ }^{17}$ determined the applicability of the correlation between the experimental values of the fatigue-crack propagation rates in the TC4 alloy at various temperatures. Lin et al. ${ }^{18}$ introduced probability theory into models of the flow behaviour to describe the most probable flow characteristics of the TC4 alloy. Although many efforts have been made to develop the constitutive equations for various materials by means of isothermal compression tests across a wide range of temperatures and strain rates, the hot-compressive deformation behaviour of the TC4 alloy needs to be further investigated to establish the optimal hot-formation process parameters.

The objective of this study is to experimentally investigate the general nature of the effects of strain, strain rate, and deformation temperature on the hot-compressive deformation characteristics of TC4 by conducting isothermal compression tests. A series of compressions are conducted at different temperatures and strain rates, and the stress-strain data are collected. On the basis of the experimental results, a comprehensive model describing the relationships of the flow stress, strain rate, and temperature of the alloys at elevated temperatures in terms of strain compensation is then proposed. The validity of the descriptive results based on the proposed constitutive equation is also investigated.

\section{EXPERIMENTAL PART}

The chemical composition of the TC4 alloy used in this study is given in Table 1. Cylindrical compressive specimens with a diameter of $10 \mathrm{~mm}$ and a height of 15 $\mathrm{mm}$ were machined, as shown in Figure 1a. To minimise the friction between the specimen and the die during the hot deformation, the flat ends of the specimen were recessed to a depth of $0.2 \mathrm{~mm}$ to trap the lubricant (graphite mixed with machine oil), and tantalum foils with high-temperature lubricants were used between the sample and the dies. Isothermal compression tests were conducted on a Gleeble thermo-simulation machine at temperatures of $(700,800$, and 900$){ }^{\circ} \mathrm{C}$ and at strain rates of $\left(0.1,1.0\right.$, and 10.0) $\mathrm{s}^{-1}$, as shown in Figure 1b. Each specimen was heated to the deformation temperature at a rate of $10{ }^{\circ} \mathrm{C} / \mathrm{s}$ and held for $300 \mathrm{~s}$ to obtain a uniform temperature distribution in the steady state. The deformation degree was $60 \%$ for all the specimens. The true stress-strain curves were recorded automatically during the isothermal compression process. After compression, the specimens were promptly quenched with water.

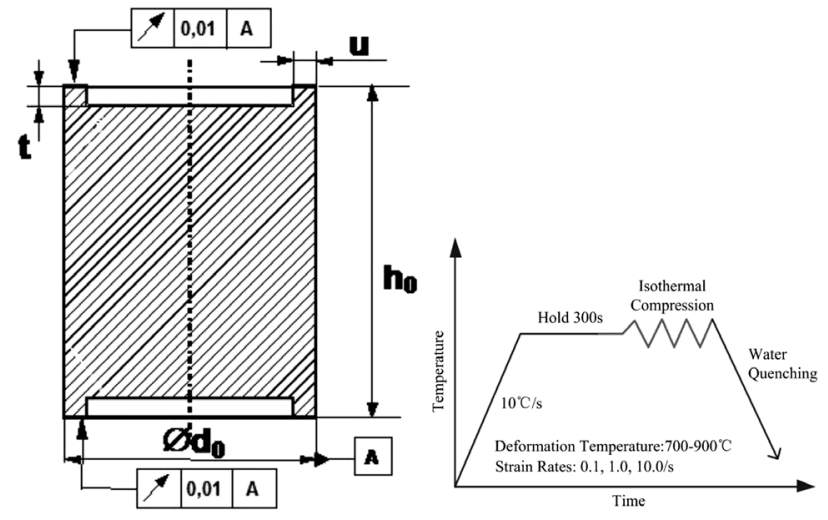

Figure 1 Sample size diagram and experiment on high-temperature compression: a) sample size diagram, b) experiment

\section{METHODOLOGY}

\subsection{Conventional constitutive model}

During hot deformation, the potential for atomic diffusion and the driving force for dislocation movement depend on the deformation temperature. The growth velocity of the dislocation densities and the grain-boundary energy depend on the strain rate. Therefore, the peak stress was conventionally considered to depend on the deformation temperature and the strain rate. On the basis of the above statements, the following constitutive model was proposed by Sellars and Tegart ${ }^{19}$ to calculate the activation energy for hot deformation.

$$
\dot{\varepsilon}=A F(\sigma) \exp \left(-\frac{Q}{R T}\right)
$$

where $F(\sigma)$ is a function of the flow stress. The function has three forms, depending on the flow-stress level. Under low-stress conditions, the relationship between the flow stress and the strain rate can be expressed as

$$
\dot{\varepsilon}=A_{1} \sigma^{n_{1}} \exp \left(-\frac{Q}{R T}\right) \quad \alpha \sigma<0.8
$$

Under high-stress conditions, this relationship can be expressed as

$$
\dot{\varepsilon}=A_{2} \exp (\beta \sigma) \exp \left(-\frac{Q}{R T}\right) \quad \alpha \sigma>1.2
$$

At any other stress level, this relationship can be expressed as

$$
\dot{\varepsilon}=A[\sinh (\alpha \sigma)]^{n} \exp \left(-\frac{Q}{R T}\right)
$$

where $A, A_{1}$, and $A_{2}$ are material constants; $n$ and $n_{1}$ are the stress exponents; $\alpha$ and $\beta$ are the stress-level parameters $(\alpha=\beta / n)$; and $R$ is the molar gas constant

Table 1: Chemical composition of TC4 alloy (w/\%)

\begin{tabular}{|c|c|c|c|c|c|c|c|}
\hline $\mathrm{Al}$ & $\mathrm{V}$ & $\mathrm{Fe}$ & $\mathrm{O}$ & $\mathrm{N}$ & $\mathrm{C}$ & $\mathrm{H}$ & $\mathrm{Ti}$ \\
\hline 6.02 & 3.78 & 0.052 & 0.18 & 0.0062 & 0.008 & 0.0049 & Balance \\
\hline
\end{tabular}



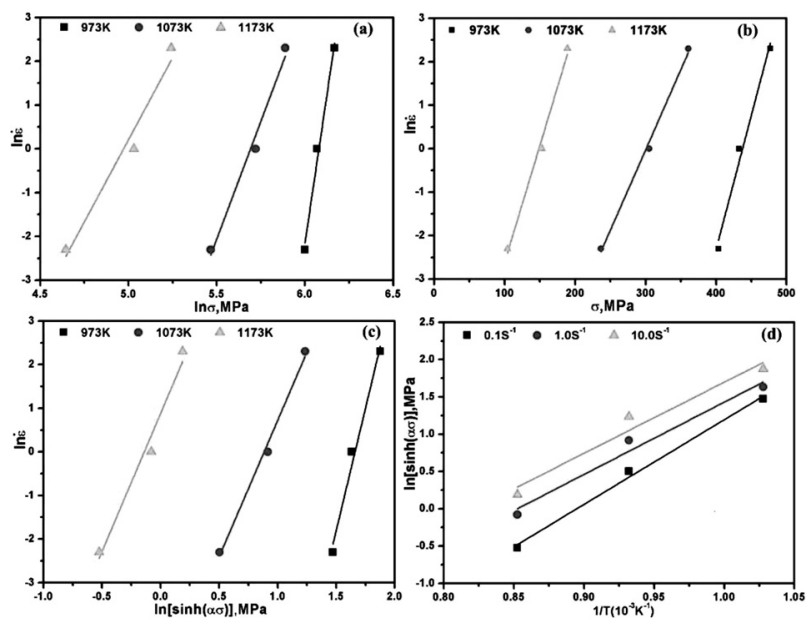

Figure 2: Relationships among the material constants

$(\mathrm{J} / \mathrm{mol} \cdot \mathrm{K}) . T$ is the absolute deformation temperature $(\mathrm{K}) ; Q$ is the deformation activation energy $(\mathrm{kJ} / \mathrm{mol})$, which shows how easily the material is hot deformed; $\dot{\varepsilon}$ is the strain rate $\left(\mathrm{s}^{-1}\right)$; and $\sigma$ is the flow stress $(\mathrm{MPa})$ for a given strain. According to the above formulas, the deformation activation energy $Q$ can be calculated as follows.

$$
Q=\left.\left.R \cdot \frac{\partial \ln \dot{\varepsilon}}{\partial[\sinh (\alpha \sigma)]}\right|_{T} \cdot \frac{\mathrm{d}\{l \ln [\sinh (\alpha \sigma)]\}}{\mathrm{d}(1 / T)}\right|_{\dot{\varepsilon}}
$$

The values of $n_{1}$ and $\beta$ can be calculated as the mean slopes of the plots of ln $\varepsilon$ against $\ln \sigma$ and $\sigma$, respectively, as shown in Figures $2 \mathbf{a}$ and $\mathbf{2 b}$. The values of $n_{1}$ and $\beta$ were $9.13 \mathrm{MPa}^{-1}$, and $0.049 \mathrm{MPa}^{-1}$, respectively. According to the equation, the mean slope of $\ln \varepsilon$ against

$\ln [\sinh (\alpha \sigma)]$ was used for calculating the values of $n$, as shown in Figure 2c. The value of $n$ was calculated to be 7.94. The value of the activation energy $Q$ was calculated as the average of the slopes of the plot of $\ln [\sinh (\alpha \sigma)]$ against $10^{3} / T$, as shown in Figure $2 d$. The values of $Q$ and $A$ were determined to be $672.366 \mathrm{~kJ} / \mathrm{mol}$ and $3.65 \times 10^{29}$, respectively.

According to Zener and Hollomon, ${ }^{20}$ the effects of the temperature and the strain rate on the deformation behaviour can be represented by a Zener-Hollomon parameter in an exponent-type equation. The hyperbolic law in an Arrhenius-type equation gives a better approximation between the Zener-Hollomon parameter and the flow stress, as follows:

$$
Z=\mathrm{A}[\sinh (\alpha \sigma)]^{n}=\dot{\varepsilon} \exp \left(\frac{Q}{R T}\right)
$$

By substituting the values of $\alpha, n, A$, and $Q$ into the peak stress constitutive equation of hot deformation for the TC4 alloy, the equation can be expressed as follows:

$$
\begin{aligned}
& \sigma=\frac{1}{0.0054} . \\
& \cdot \ln \left\{\left(\frac{Z}{3.65 \times 10^{29}}\right)^{\frac{1}{7.938}}+\left[\left(\frac{Z}{3.65 \times 10^{29}}\right)^{\frac{2}{7.938}}+1\right]^{\frac{1}{2}}\right\}
\end{aligned}
$$

In addition, the Zener-Hollomon parameter for the TC4 alloy can be represented as follows:

$$
Z=\dot{\varepsilon} \exp \left(\frac{672366}{R T}\right)
$$
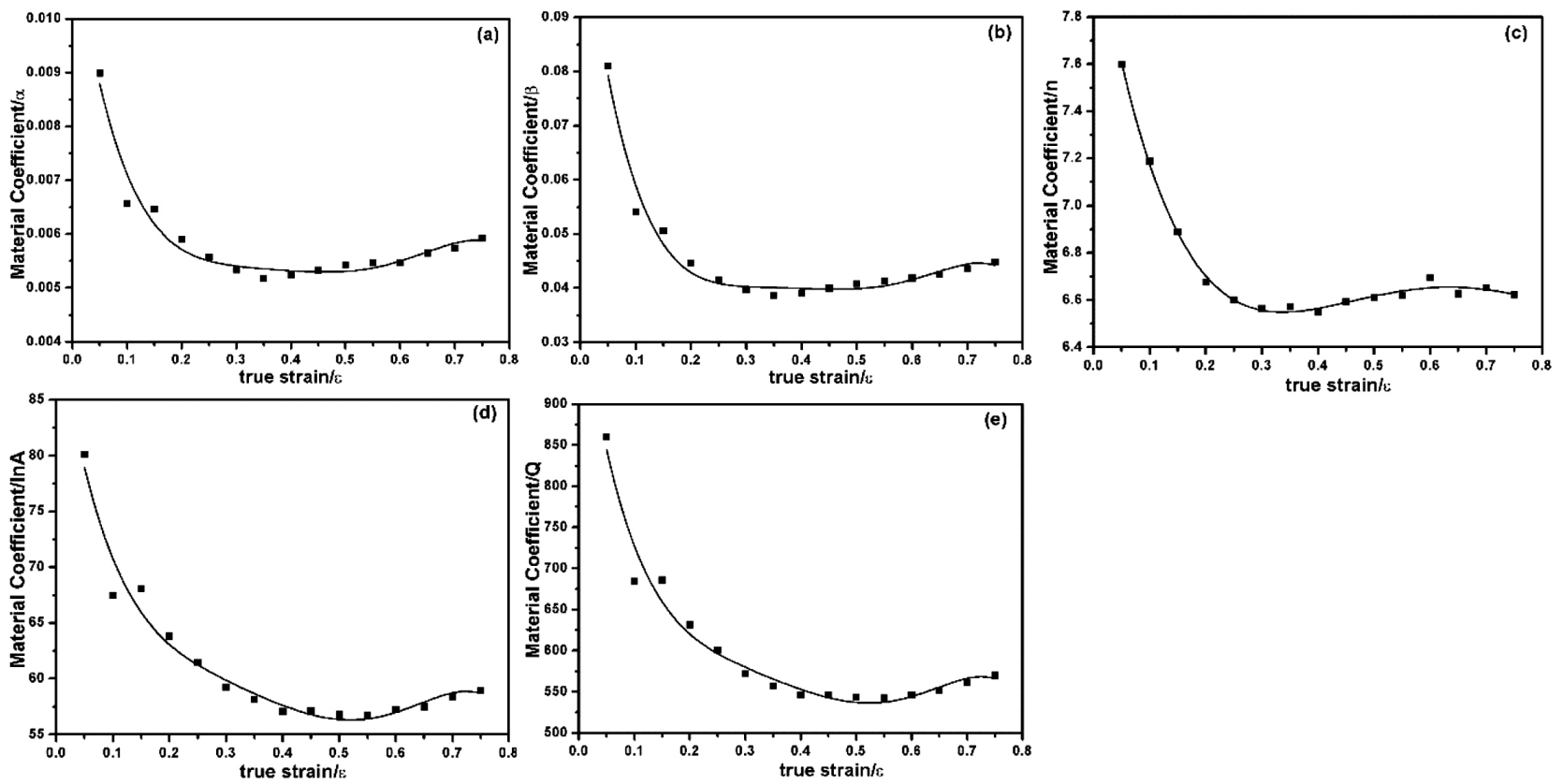

Figure 3: Relationships among $Q, \ln A, n, \alpha, \beta$, and the true strain of the TC4 alloy obtained by polynomial fitting 


\subsection{Developed constitutive model}

In the conventional constitutive model mentioned above, the influence of the strain on the flow stress of the sample is not taken into account. In fact, as the strain changes, the values of the material parameters also change. Therefore, to improve the accuracy of the constitutive model, the effects of the deformation strain on the flow stress of the TC4 alloy were studied. ${ }^{21}$ A series of constitutive equations with different values of the material constants $Q, \ln A, n, \alpha$, and $\beta$ for strain values ranging from 0.05 to 0.75 at intervals of 0.05 were developed using the method to deduce the constitutive equation of the peak stress. The relationships among $Q$, $\ln A, n, \alpha, \beta$, and the true strain of the TC4 alloy are shown in Figure 3.

$\left\{\begin{array}{l}\alpha=a_{5} \varepsilon^{5}+a_{4} \varepsilon^{4}+a_{3} \varepsilon^{3}+a_{2} \varepsilon^{2}+a \varepsilon+a_{0} \\ \beta=b_{5} \varepsilon^{5}+b_{4} \varepsilon^{4}+b_{3} \varepsilon^{3}+b_{2} \varepsilon^{2}+b \varepsilon+b_{0} \\ n=c_{5} \varepsilon^{5}+c_{4} \varepsilon^{4}+c_{3} \varepsilon^{3}+c_{2} \varepsilon^{2}+c \varepsilon+c_{0} \\ \ln A=d_{5} \varepsilon^{5}+d_{4} \varepsilon^{4}+d_{3} \varepsilon^{3}+d_{2} \varepsilon^{2}+d \varepsilon+d_{0} \\ Q=e_{5} \varepsilon^{5}+e_{4} \varepsilon^{4}+e_{3} \varepsilon^{3}+e_{2} \varepsilon^{2}+e \varepsilon+e_{0}\end{array}\right.$

Furthermore, the values of $Q, \ln A, n, \alpha$, and $\beta$ can be expressed as polynomial functions, as above.

The coefficients of the polynomial functions are provided in Table 2.

Table 2: Results of the polynomial fitting of $Q, \ln A, b, n, \alpha$, and $\beta$ for the TC4 alloy

\begin{tabular}{|c|c|c|c|c|c|}
\hline \multicolumn{2}{|r|}{$\alpha$} & \multicolumn{2}{|r|}{$\beta$} & \multicolumn{2}{|r|}{$n$} \\
\hline$a_{5}$ & -0.37619 & $b_{5}$ & -4.62233 & $c_{5}$ & -10.9307 \\
\hline$a_{4}$ & 0.86415 & $b_{4}$ & 10.69921 & $c_{4}$ & 42.28069 \\
\hline$a_{3}$ & -0.76358 & $b_{3}$ & -9.53864 & $c_{3}$ & -63.8437 \\
\hline$a_{2}$ & 0.33022 & $b_{2}$ & 4.13316 & $c_{2}$ & 45.00507 \\
\hline$a_{1}$ & -0.07135 & $b_{1}$ & -0.87862 & $c_{1}$ & -14.3451 \\
\hline$a_{0}$ & 0.01162 & $b_{0}$ & 0.11398 & $c_{0}$ & 8.21768 \\
\hline \multicolumn{2}{|r|}{$\ln \mathrm{A}$} & \multicolumn{2}{|r|}{$Q$} & & \\
\hline$d_{5}$ & -2181.66 & $e_{5}$ & -29534.3 & & \\
\hline$d_{4}$ & 4739.634 & $e_{4}$ & 65271.74 & & \\
\hline$d_{3}$ & -3905.82 & $e_{3}$ & -54909.5 & & \\
\hline$d_{2}$ & 1578.533 & $e_{2}$ & 22617.27 & & \\
\hline$d_{1}$ & -341.295 & $e_{1}$ & -4899.78 & & \\
\hline$d_{0}$ & 92.55066 & $e_{0}$ & 1039.822 & & \\
\hline
\end{tabular}

\section{RESULTS AND DISCUSSION}

\subsection{Hot-deformation flow curves}

The microstructural evolution during hot deformation is very complicated and is affected by multiple physical mechanisms, such as work hardening and dynamic recovery (DRV) and dynamic recrystallisation (DRX) softening. At the macroscale, the changes in the flow stress varied with the process parameters, such as the temperature, strain rate, and extent of deformation. The true stress-strain curves obtained from the hot-compression tests at different deformation temperatures and strain rates are shown in Figure 4. The flow curves obtained at different deformation temperatures and strain rates clearly have similar variations. That is, the flow stress initially increases quickly with an increase in the strain. Then the rising trend continues until the peak flow stress is reached. Finally, the flow stress maintains a stable value and does not change with an increase in the strain. Under the same strain rate, the flow stress decreases with an increase in the deformation temperature. However, under the same deformation temperature, the flow stress increases with an increase in the strain rate.

According to Mohamadizadeh et al., ${ }^{22}$ Chen et al., ${ }^{23}$ and Guo et al., ${ }^{24}$ this phenomenon is explained as
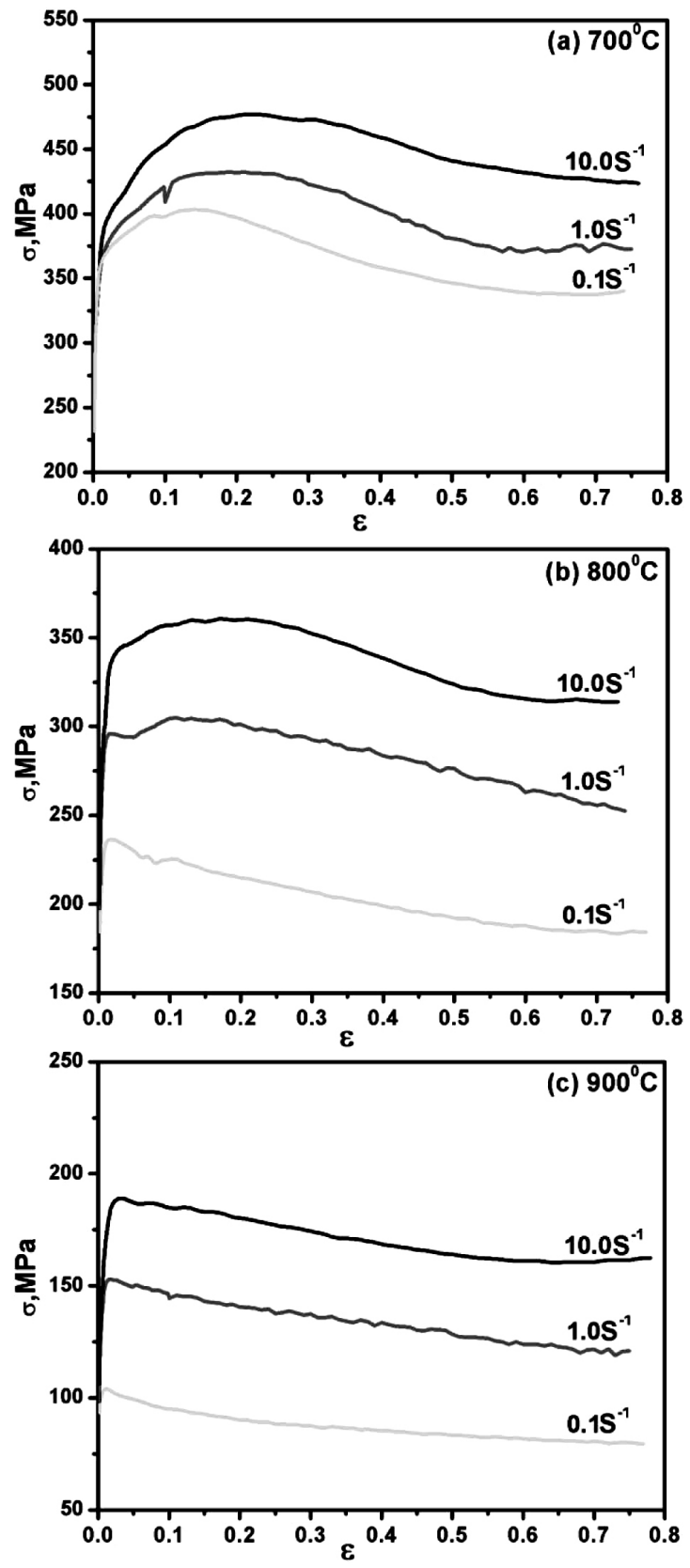

Figure 4: Flow-stress curves of the TC4 alloy at different strain rates 
follows. Hot deformation is a thermally activated process. The kinetic energy of the atoms increases and the binding force between the atoms decreases as the temperature increases, so dislocation gliding becomes easier. Further, the sliding resistance decreases and the generation of new slip systems is enhanced with a decrease in the strain rate and an increase in the deformation temperature. As a result, the softening effect during deformation increases, and the critical shear stress decreases; that is, the minimum shear stress required for the slip systems to slide is reduced. In addition, as the strain rate increases, the rate of dislocation propagation due to work hardening increases, and the dislocation movement inside the material also increases. DRV and DRX proceed easily at elevated temperatures and low strain rates. At deformation temperatures of less than $800{ }^{\circ} \mathrm{C}$ and strain rates exceeding $1.0 \mathrm{~s}^{-1}$, the main softening mechanism of the TC4 alloy is DRX. The flow stress increases to the maximum and then decreases to a certain value between the peak stress and the steady-state stress. The TC4 alloy usually has this characteristic in the $\alpha+\beta$ phase. For example, this behaviour appears in the flow-stress curves obtained at $700{ }^{\circ} \mathrm{C}$ and $10.0 \mathrm{~s}^{-1}$ and at $800{ }^{\circ} \mathrm{C}$ and $10.0 \mathrm{~s}^{-1}$. At low and moderate strain rates $\left(0.1 \mathrm{~s}^{-1}\right.$ and $1.0 \mathrm{~s}^{-1}$, respectively), the deformation temperature of the TC4 alloy increases at this time. The magnitude of the stress reduction after the peak stress will decrease with a decrease in the temperature and an increase in the strain rate. At this time, the main softening mechanism of the alloy is DRV. In addition, it is accompanied by a temperature reduction and a decrease in the flow-stress curve, which may be caused by partial DRX. For example, this behaviour appears in the flow-stress curves obtained at $800{ }^{\circ} \mathrm{C}$ and $0.1 \mathrm{~s}^{-1}$ and at $900{ }^{\circ} \mathrm{C}$ and $1.0 \mathrm{~s}^{-1}$.

\subsection{Verification of developed constitutive equations}

To verify the developed constitutive equation of the TC4 alloy at elevated temperatures, the experimental and predicted flow stresses are compared using the developed constitutive equations, as shown in Figure 5.

To evaluate the accuracy of the developed constitutive equation, the relative errors between the predicted and measured flow stress are also calculated, as follows: 25

$$
\Delta_{\text {error }}=\frac{\sigma_{\mathrm{p}}-\sigma_{\mathrm{m}}}{\sigma_{\mathrm{m}}} \times 100 \%
$$

Further, the average relative error is expressed as

$$
\Delta_{\mathrm{AARE}}=\frac{1}{N} \sum_{i=1}^{N}\left|\frac{\sigma_{\mathrm{p}}-\sigma_{\mathrm{m}}}{\sigma_{\mathrm{m}}}\right| \times 100 \%
$$

where $\sigma_{\mathrm{m}}$ is the measured flow stress, and $\sigma_{p}$ is the predicted flow stress obtained from the developed constitutive equation considering strain compensation. $N$ is the total number of data points used in this study,
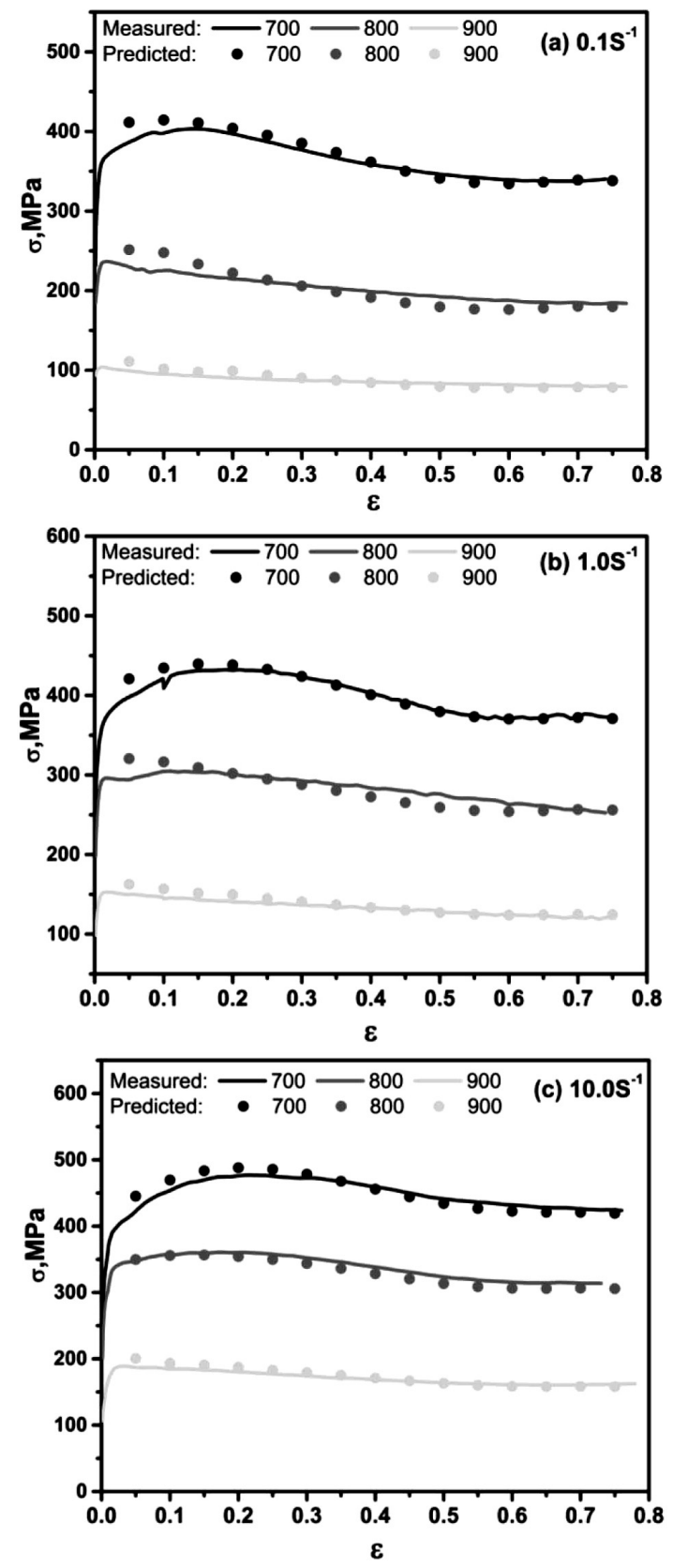

Figure 5: Comparison of predicted and measured flow-stress curves of the TC4 alloy

and $\Delta_{\text {error }}$ and $\Delta_{\mathrm{AARE}}$ are the relative error and average relative error, respectively, between the predicted and measured flow stress.

This calculation revealed that the maximum relative error and the average relative error between the predicted and experimental results were $10.56 \%$ and $2.88 \%$, respectively. Figure 5 shows that in the initial stage of compression, i.e., when the strain is approximately 0.005 , work hardening plays a dominant role, and the effect of the work-hardening rate is not considered in the constitutive model. Therefore, the prediction has certain errors. However, the predicted values of the other data 
are in good agreement with the experimental values, which shows that the improved flow-stress constitutive model considering strain compensation can better predict the flow stress of the TC4 alloy at high temperatures. It can be used to analyse the high-temperature rheological behaviour of the TC4 alloy during hot processing, provide guidance for a calculation of the deformation resistance in the actual forging process, and provide a basis for numerical simulation.

\section{CONCLUSIONS}

The flow behaviour and flow stress of the TC4 alloy were studied by isothermal compression tests. Further, a revised constitutive model describing the relationship among the flow stress, strain rate, and forming temperature of the TC4 alloy at elevated temperature was established. The achievements of the current research are summarised as follows:

(1) The hot-compressive deformation behaviour of the TC4 alloy was investigated through isothermal compression tests; the obtained results clearly indicated that DRV and DRX occurred during hot compression.

(2) On the basis of the experimental results and regression methods, the activation energy of the hot deformation $Q$ is determined to be $672.366 \mathrm{~kJ} / \mathrm{mol}$.

(3) The developed constitutive equation considering strain compensation can correctly predict the flow stress. The maximum relative error and the average relative error between the predicted and experimental results were $10.56 \%$ and $2.88 \%$, respectively. These values confirm that the developed constitutive model is suitable for studying the hot-compressive deformation behaviour of the TC4 alloy.

\section{REFERENCES}

${ }^{1}$ Y. G. Liu, M. Q. Li, H. J. Liu, Surface nanocrystallization and gradient structure developed in the bulk TC4 alloy processed by shot peening, J. Alloy. Compd., 685 (2016), 186-193, doi:10.1016/ j.jallcom.2016.05.295

${ }^{2}$ J. Sun, Y. B. Guo, Material flow stress and failure in multiscale machining titanium alloy Ti-6Al-4V, Int. J. Adv. Manuf. Technol., 41 (2009) 7-8, 651-659, doi:10.1007/s00170-008-1521-6

${ }^{3}$ Y. G. Liu, M. Q. Li, H. J. Liu, Deformation induced face-centered cubic titanium and its twinning behavior in Ti-6Al-4V, Scr. Mater., 119 (2016), 5-8, doi:10.1016/j.scriptamat.2016.03.018

${ }^{4}$ R. Bobbili, B. V. Ramudu, V. Madhu, A physically-based constitutive model for hot deformation of Ti-10-2-3 alloy, J. Alloy. Compd., 696 (2016), 295-303, doi:10.1016/j.jallcom.2016.11.208

${ }^{5}$ J. Cai, K. S. Wang, C. P. Miao, Constitutive analysis to predict hightemperature flow behavior of BFe10-1-2 cupronickel alloy in consideration of strain, Mater. Design, 65 (2015) 2, 272-279, doi:10.1016/j.matdes.2014.09.028

${ }^{6}$ Y. C. Lin, M. S. Chen, A critical review of experimental results and constitutive descriptions for metals and alloys in hot working, Mater. Design, 32 (2011) 4, 1733-1759, doi:10.1016/j.matdes. 2010.11.048 ${ }^{7}$ G. Chen, C. Ren, X. Qin et al., Temperature dependent work hardening in Ti-6Al-4V alloy over large temperature and strain rate ranges: experiments and constitutive modeling, Mater. Design, 83 (2015), 598-610, doi:10.1016/j.matdes.2015.06.048
${ }^{8}$ J. H. Kim, S. L. Semiatin, Y. H. Lee et al., A self-consistent approach for modeling the flow behavior of the alpha and beta phases in Ti-6Al-4V, Metall. Mater. Trans. A Phys. Metall. Mater. Sci., 42 (2011) 7, 1805-1814, doi:10.1007/s11661-010-0567-x

${ }^{9}$ Y. G. Liu, M. Q. Li, J. Luo, The modelling of dynamic recrystallization in the isothermal compression of $300 \mathrm{M}$ steel, Mater. Sci. Eng. A, 574 (2013) 6, 1-8, doi:10.1016/j.msea.2013.03.011

${ }^{10}$ X. L. Hou, Y. Li, P. Lv et al., Hot deformation behavior and microstructure evolution of a Mg-Gd-Nd-Y-Zn alloy, Rare Met., 35 (2016) 7, 532-536, doi:10.1007/s12598-015-0507-4

${ }^{11}$ Y. Kim, Y. B. Song, S. H. Lee et al., Characterization of the hot deformation behavior and microstructural evolution of Ti-6Al-4V sintered preforms using materials modeling techniques, J. Alloy. Compd., 676 (2016), 15-25, doi:10.1016/j.jallcom.2016.03.146

${ }^{12}$ F. Wang, J. Zhao, N. Zhu et al., A comparative study on Johnson-Cook constitutive modeling for Ti-6Al-4V alloy using automated ball indentation (ABI) technique, J. Alloy. Compd., 633 (2015), 220-228, doi:10.1016/j.jallcom.2015.01.284

${ }^{13}$ J. Xiao, D. S. Li, X. Q. Li et al., Constitutive modeling and microstructure change of Ti-6Al-4V during the hot tensile deformation, J. Alloy. Compd., 541 (2012) 1, 346-352, doi:10.1016/j.jallcom. 2012.07.048

${ }^{14}$ Z. W. Yuan, F. G. Li, H. J. Qiao et al., A modified constitutive equation for elevated temperature flow behavior of Ti-6Al-4V alloy based on double multiple nonlinear regression, Mater. Sci. Eng. A, 578 (2013), 260-270, doi:10.1016/j.msea.2013.04.091

${ }^{15}$ N. Kotkunde, H. N. Krishnamurthy, P. Puranik et al., Microstructure study and constitutive modeling of Ti-6Al-4V alloy at elevated temperatures, Mater. Design, 54 (2014) 2, 96-103, doi:10.1016/ j.matdes.2013.08.006

${ }^{16}$ X. Q. Li, G. Q. Guo, J. J. Xiao et al., Constitutive modeling and the effects of strain-rate and temperature on the formability of Ti-6Al-4V alloy sheet, Mater. Design, 55 (2014) 6, 325-334, doi:10.1016/j.matdes.2013.09.069

${ }^{17}$ A. A. Kotlyarenko, A. P. Zinkovskii, K. N. Podgorskii et al., A study of correlation between the paris equation coefficients based on the test results for titanium alloy specimens, Strength Mater., 48 (2016) 3, 341-348, doi:10.1007/s11223-016-9769-9

${ }^{18}$ Y. C. Lin, C. Y. Zhao, M. S. Chen et al., A novel constitutive model for hot deformation behaviors of Ti-6Al-4V alloy based on probabilistic method, Appl. Phys. A, 122 (2016) 8, doi:10.1007/s00339016-0248-8

${ }^{19}$ J. J. Jonas, C. M. Sellars, W. J. M. Tegart, Strength and structure under hot-working conditions, Int. Mater. Rev., 14 (1969) 1, 1-24, doi:10.1179/mtlr.1969.14.1.1

${ }^{20}$ C. Zener, J. H. Hollomon, Effect of strain rate upon plastic flow of steel, J. Appl. Phys., 15 (1944) 1, 22-32, doi:10.1063/1.1707363

${ }^{21}$ Y. C. Lin, M. S. Chen, J. Zhong, Constitutive modeling for elevated temperature flow behavior of 42CrMo steel, Comp. Mater. Sci., 42 (2008) 3, 470-477, doi:10.1016/j.commatsci.2007.08.011

${ }^{22}$ A. Mohamadizadeh, A. Zarei-Hanzaki, H. R. Abedi et al., Hot deformation characterization of duplex low-density steel through 3D processing map development, Mater. Charact., 107 (2015), 293-301, doi:10.1016/j.matchar.2015.07.028

${ }^{23}$ L. Chen, Y. J. Zhang, F. Li et al., Modeling of dynamic recrystallization behavior of $21 \mathrm{Cr}-11 \mathrm{Ni}-\mathrm{NRE}$ lean austenitic heat-resistant steel during hot deformation, Mater. Sci. Eng. A, 663 (2016), 141-150, doi:10.1016/j.msea.2016.03.119

${ }^{24}$ L. F. Guo, Z. M. Zhang, B. C. Li et al., Modeling the constitutive relationship of powder metallurgy Al-W alloy at elevated temperature, Mater. Design, 64 (2014), 667-674, doi:10.1016/j.matdes. 2014.08.031

${ }^{25}$ S. Seo, O. Min, H. Yang, Constitutive equation for Ti-6Al-4V at high temperatures measured using the SHPB technique, Int. J. Impact Eng., 31 (2005) 6,735-754, doi:10.1016/j.ijimpeng.2004. 04.010 